\title{
Degradabilidade ruminal "in situ" da matéria seca, matéria orgânica e proteína bruta de alguns suplementos concentrados usados na alimentação de bovinos
}

\section{In situ ruminal degradability of dry matter, organic matter and crude protein of some concentrated supplements used in the feeding of bovines}

\author{
Fernando Henrique Brussi Beran ${ }^{1}$; Leandro das Dores Ferreira da Silva ${ }^{2 *}$; Edson \\ Luis de Azambuja Ribeiro ${ }^{3}$; Valdecir de Souza Castro ${ }^{3}$; Romulo Alexandre Correa ${ }^{4}$; \\ Énio Ossamu Kagueyama ${ }^{5}$; Marco Antônio da Rocha ${ }^{3}$
}

\section{Resumo}

\begin{abstract}
Foram utilizados quatro bovinos da raça holandesa, machos castrados, fistulados no rúmen, pesando em média $650 \mathrm{~kg}$, mantidos em pastejo e recebendo mistura mineral "ad libtum". O presente trabalho teve como objetivo avaliar a degradação ruminal "in situ" da matéria seca (MS), proteína bruta (PB) e matéria orgânica (MO) de 12 alimentos concentrados: grão de girassol integral (GI), grão de girassol parcialmente desengordurado (GD), farelo de girassol (FG), torta de girassol com uma passagem pela prensa ( $\mathrm{T} 1 \mathrm{x})$, torta de girassol com duas passagens pela prensa ( $2 \mathrm{x}$ ), para retirada do óleo, grão de soja comercial (SI), grão de soja comercial parcialmente desengordurado (SD), farelo de soja (FS), caroço de algodão (CA), farelo de algodão (FA), gérmen de milho desengordurado (GM) e um concentrado comercial com $36 \%$ de $\mathrm{PB}(\mathrm{CC})$. Os alimentos foram moídos em moinhos dotados com peneira com crivos de $2 \mathrm{~mm}$ de diâmetro. Foram incubados $5 \mathrm{~g}$ de MS de cada um dos alimentos citados em sacos de náilon com poros de diâmetro de 50 micras, medindo $14 \times 7 \mathrm{~cm}$, para os tempos de 12;20; e $33 \mathrm{~h}$ de fermentação ruminal. As degradabilidades efetivas (DE) da PB a uma taxa de passagem de 5\%/h variaram de 62,08 a 95,93\% para CC e TG2, e a MO de 85,28 a 48,17\% para FS e CA. O CC e o GM apresentaram as menores DE da PB, porém somente o $\mathrm{CC}$ teria maiores escapes de proteína para ser digerida nos intestinos, pois o GM apresenta pouca PB em sua constituição.

Palavras-chave: Caroço de algodão, farelo de algodão, farelo de girassol, farelo de soja, soja integral, torta de girassol
\end{abstract}

\begin{abstract}
Holstein steers, with permanent ruminal cannula, $650 \mathrm{~kg}$ of liveweight, maintained on pasture, and receiving mineral mixture "ad libtum" were used. The present study had the objective of evaluating the "in situ" ruminal degradation of the dry matter (DM), crude protein (CP) and organic matter (OM) of 12 concentrated feed: whole sunflower seed (WSF), partially degreased sunflower (DSF), sunflower meal
\end{abstract}

\footnotetext{
Aluno de Pós-graduação em Ciência Animal (área de concentração: Produção Animal), UEL.

2 Professores do Dep. de Zootecnia da UEL Caixa Postal 6001, CEP 86051-990. Londrina-PR. Leandro@uel.br.

3 Aluno de graduação do Curso de Zootecnia da UEL.

4 Aluno de Pós-graduação em Ciência Animal (área de concentração: Produção Animal), UEL.

5 Aluno de graduação do Curso de Medicina Veterinária da UEL.

* Autor para correspondência.
} 
(SFM), sunflower pie pressed one time (T 1x), sunflower pie pressed two time (T 2x), for extracting of the oil, whole soybean seed (WS), partially degreased soybean (DS), soybean meal (SM), whole cottonseed (WC), cottonseed meal (CM), degreased corn germ (CG) and a commercial concentrate with $36 \%$ of CP (CC). The feed were grounded in a mill equipped with a screen with sieves of $2 \mathrm{~mm}$ of diameter. Samples $5 \mathrm{~g}$ of DM from each one of the mentioned feed were incubated in nylon bags with pores of 50 micras of diameter, measuring $14 \times 7 \mathrm{~cm}$, for the times of 12;20; and $33 \mathrm{~h}$ of ruminal fermentation. The effective degradability (ED) of CP, for a passage rate of $5 \% / \mathrm{h}$ varied from 62.08 to $95.93 \%$ for commercial concentrate and sunflower pie pressed two time for OM varied from 48.17 to $85.28 \%$ for soybean meal and whole cottonseed. The CC and CG presented the smallest ED of CP, however only the CC have larger protein escapes to be digested in the intestines, because CG presents little PB in its constitution.

Key words: Whole cottonseed, cottonseed meal, sunflower meal, soybean meal, whole soybean, sunflower pie.

\section{Introdução}

No Brasil, a produção de bovinos, é basicamente realizada em pastagens natural ou cultivada. É necessário aumentar a taxa de desfrute nas pequenas propriedades, tornando-as mais lucrativas. Para se conseguir tais objetivos em animais ruminantes, os fornecimentos de energia, proteína, minerais e de algumas vitaminas em quantidade e qualidade tornase relevante no contexto produtivo. Para a terminação a pasto, quando se objetiva maiores níveis produtivos, há necessidade de se suplementar os animais com ração concentrada, devido o pasto não apresentar níveis suficientes daqueles componentes nutritivos para atender os níveis produtivos desejados.

As exigências de proteína dos animais ruminantes são atendidas pelos aminoácidos absorvidos no intestino delgado, sendo estes provenientes principalmente da proteína microbiana e da proteína dietética não degradada no rúmen. Tanto o sistema americano National Research Council (1985; 1989), como o britânico AFRC (1993), calcula as exigências protéicas em função da proteína metabolizável. No entanto, para que animais altamente produtivos possam expressar seu potencial genético, é preciso maximizar a eficiência da síntese de proteína microbiana e da proteína não degradada no rúmen (VALADARES FILHO; VALADARES, 2001). Sincronizando a liberação da amônia e a fermentação dos carboidratos a uma mesma taxa de degradação promove-se a maximização da síntese de proteína microbiana, aumentando a ingestão de proteína metabolizável. Esta, também, pode ser aumentada com o fornecimento de proteínas de baixa degradação, com maior escape a fermentação ruminal, sendo este processo influenciado pela taxa de passagem (MARTINS et al.,1999).

$\mathrm{O}$ crescente interesse por parte da indústria na exploração de oleaginosas, por exemplo, o girassol, tem refletido em aumentos na disponibilidade de coprodutos. Além disto, tem havido crescimento na comercialização de rações e de concentrados comerciais. O presente trabalho teve como objetivo determinar as degradabilidades "in situ" em bovinos, de alimentos concentrados oriundos da agroindústria, compostos por girassol, soja, algodão, gérmen de milho e um concentrado comercial, com tempos de permanência ruminal, de $33 ; 20$ e 12 horas, correspondentes as taxas de passagens de $3 \% / \mathrm{h}$, e as preconizadas pelo Agricultural and Food Research Council (1993), de 5 e $8 \% / \mathrm{h}$, podendo assim determinar a quantidade de proteína que escapa a fermentação ruminal.

\section{Material e métodos}

O experimento foi realizado na Fazenda Escola e no Laboratório de Nutrição Animal do Departamento de Zootecnia vinculados ao Centro de Ciências Agrárias da Universidade Estadual de Londrina, no período de março de 2003 a março de 2004.

Foram utilizados quatro bovinos da raça Holandesa, machos castrados, em idade adulta, tendo 
em média $650 \mathrm{~kg}$ de peso, dotados de cânula permanente no rúmen. Os animais foram vermifugados antes de iniciar a fase experimental com ivermectina e pulverizados com amitraz, para combater ectoparasitas.

Os animais foram mantidos em pastagem com capim colonião (Panicum maximum), por todo período experimental. Foram submetidos a um período de 15 dias de adaptação, recebendo diretamente via cânula ruminal, $4 \mathrm{~kg}$ de concentrado composto com milho e com quantidades proporcionais dos ingredientes a serem analisados, duas vezes ao dia, às 7 e às 18 horas. Além disso, foi disponibilizado, aos animais, mistura mineral e água "ad libitum".

Os 12 alimentos concentrados usados na incubação "in situ” foram: grão de girassol (GI), grão de girassol parcialmente desengordurado (GD), farelo de girassol (FG), torta de girassol, com 1 passagem pela prensa ( $\mathrm{T} 1 \mathrm{x})$, torta de girassol, com 2 passagens pela prensa ( $\mathrm{T} 2 \mathrm{x}$ ), para retirada de óleo, grão de soja comercial (SI), grão de soja comercial parcialmente desengordurado (SD), farelo de soja (FS), caroço de algodão (CA), farelo de algodão (FA), gérmen de milho desengordurado (GM), concentrado comercial com $36 \%$ de PB (CC). A composição dos alimentos encontra-se na Tabela 1 .
Os grãos de soja e girassol, triturados em moinho dotados com peneira com crivos de $2 \mathrm{~mm}$ de diâmetro, desengordurados foram obtidos a partir de porções de $200 \mathrm{~g}$ de matéria natural, lavadas em éter de petróleo durante seis horas, posteriormente misturadas e homogeneizadas para a colocação nos sacos de náilon.

O concentrado comercial (CC) apresentava no rótulo $87 \%$ de matéria seca máxima, mínimo de $36 \%$ de proteína bruta $(\mathrm{PB})$, máximo de $8 \%$ de nitrogênio não protéico (NNP), máximo de $15 \%$ de matéria mineral (MM), mínimo de $2 \%$ de extrato etéreo (EE). Ingredientes: calcário calcítico, farelo de soja, farelo de soja extrusado, farelo de trigo, uréia pecuária, farinha de penas hidrolisadas, aditivo promotor de crescimento (rumensin), cloreto de sódio, premix vitamínico e mineral.

As degradabilidades da matéria seca (MS), matéria orgânica (MO) e da proteína bruta (PB), dos alimentos foram determinadas pela técnica "in situ", utilizando-se sacos confeccionados em náilon 100\% poliamida, não resinado, medindo $14 \times 7 \mathrm{~cm}$, selados a quente, com poros de 50 micrômetros, contendo aproximadamente $5 \mathrm{~g}$ de matéria seca de cada um dos alimentos anteriormente citados, triturados previamente em moinho dotados de peneira com crivos de $2 \mathrm{~mm}$ de diâmetro.

Tabela 1. Composição em matéria seca (MS), proteína bruta (PB), matéria orgânica (MO) e extrato etéreo (EE), dos alimentos incubados

\begin{tabular}{lcccr}
\hline \multirow{1}{*}{ Alimentos } & \multirow{2}{*}{ MS } & \multicolumn{3}{c}{ Porcentagem na MS } \\
\cline { 3 - 5 } & & PB & MO & EE \\
\hline Grão de girassol integral & 93,24 & 15,46 & 97,36 & 38,06 \\
Girassol parcialmente desengordurado & 91,69 & 27,25 & 95,71 & 4,00 \\
Farelo de girassol & 90,36 & 29,62 & 95,10 & 1,36 \\
Torta de girassol com uma passagem & 90,58 & 22,89 & 95,83 & 23,87 \\
Torta de girasol com duas passagens & 86,40 & 27,77 & 94,98 & 25,57 \\
Soja integral & 88,27 & 40,13 & 94,87 & 21,05 \\
Soja parcialmente desengordurada & 90,14 & 51,45 & 94,27 & 7,62 \\
Farelo de soja & 89,74 & 47,53 & 93,17 & 1,60 \\
Caroço de algodão & 90,69 & 22,46 & 95,94 & 15,87 \\
Farelo de algodão & 89,85 & 38,90 & 94,10 & 0,19 \\
Gérmen de milho desengordurado & 88,03 & 10,79 & 92,65 & 0,20 \\
Concentrado comercial & 89,54 & 37,76 & 85,94 & 1,94 \\
\hline
\end{tabular}


Os sacos de náilon, em número de seis repetições por tempo, previamente pesados e com amostras individuais de cada alimento em estudo foram amarrados aos elos de uma corrente com $50 \mathrm{~cm}$ de comprimento, pesando aproximadamente $500 \mathrm{~g}$, presa por um cordão de seda à tampa da cânula, para os tempos de 12; 20 e 33 horas de permanência no rúmen, totalizando 18 sacos para cada alimento e 54 sacos por animal, para cada um dos quatro períodos de incubação. Adotou-se o sistema de tempo invertido, de tal forma que os sacos de náilon foram retirados, após as primeiras inserções completarem 33 horas no rúmen, em cada período. Os quatro períodos foram expurgado da análise estatística, pois não apresentaram significância.

Os sacos de náilon, ainda presos nas correntes, foram lavados em água fria para retirada do excesso de conteúdo ruminal e, em seguida, mergulhados por um período de 30 minutos em água com gelo para interromper a atividade dos microrganismos. Em seguida, foram retirados das correntes e lavados durante 20 minutos em uma máquina tipo Tanquinho (sendo que a cada cinco minutos a água da máquina era trocada) até que a água ficasse clara. Após esta etapa, os sacos foram pendurados em um suporte de ferro para secar, em estufa com temperatura controlada a $55^{\circ} \mathrm{C} \pm 5^{\circ} \mathrm{C}$ com circulação forçada de ar durante 48 horas.

Foram utilizados dois sacos de náilon contendo amostras de cada alimento estudado que não foram colocados no rúmen, mas que passaram pelos mesmos procedimentos daqueles com resíduos não digeridos no rúmen, para quantificações das frações solúveis dos diferentes componentes nutritivos, dos alimentos em estudo.

A fração solúvel (A) de todos os componentes nutritivos avaliados foi obtida através das diferenças entre as quantidades contidas inicialmente na amostra dos alimentos e aquelas determinadas nos resíduos após lavados, secos e triturados.

Os sacos com as amostras residuais, não digeridas e insolúveis, após secos, foram pesados e as amostras de cada alimento incubado e dos resíduos nos sacos de náilon foram trituradas a um milímetro para determinar a matéria seca, matéria mineral, proteína bruta e extrato etéreo (EE), conforme metodologias descritas por Silva e Queiroz (2002).

A fração indegradável (C) foi considerada como sendo o resíduo encontrado no saco de náilon após 33 horas de permanência no rúmen.

Para a avaliação da degradação potencial da matéria seca, matéria orgânica e proteína bruta foi utilizado o modelo proposto por Orskov e McDonald (1979); onde: $\mathrm{p}=\mathrm{a}+\mathrm{b}\left(1-\mathrm{e}^{\mathrm{kt}}\right)$, em que; $\mathrm{p}=$ degradação potencial do componente nutritivo em porcentagem, $a$ = fração solúvel em porcentagem, $b$ = fração insolúvel potencialmente degradável em porcentagem, $a+b=$ degradação potencial do componente nutritivo, $\mathrm{k}=$ taxa de digestão por ação fermentativa em porcentagem por hora e $\mathrm{t}=$ Tempo de incubação em horas

Para estimar a degradabilidade efetiva foi usada a expressão; $\mathrm{P}=\mathrm{a}+\mathrm{b} * \mathrm{k}\left(\mathrm{k}_{\mathrm{d}}+\mathrm{k}_{\mathrm{p}}\right)^{-1}$ sendo; $\mathrm{P}=$ degradabilidade efetiva em porcentagem, $\mathrm{K}_{\mathrm{p}}=$ taxa de passagem por hora, sendo que foram utilizados os valores de $\mathrm{k}_{\mathrm{p}}$ de $3 \%$ /hora, e 5 e $8 \%$ /hora, sugeridos pelo AFRC (1993), e a, b e K as mesmas constantes da equação, anteriormente citada.

Os animais foram distribuídos em delineamento experimental inteiramente ao acaso, com quatro animais e 12 tratamentos (alimentos) em um esquema de parcelas subdivididas (representadas pelos tempos de degradação).

Os dados obtidos foram submetidos à análise de variância (ANOVA), e as diferenças entre médias comparadas pelo Teste Tukey através do procedimento GLM do SAS (1990) a 5\% de probabilidade.

Os dados relativos às frações $\mathrm{B}, \mathrm{C}, \mathrm{DP}, \mathrm{DE}(3 \%)$ h), DE $(5 \% / \mathrm{h})$ e DE $(8 \% / \mathrm{h})$ de taxa de passagem, dos diferentes componentes nutritivos foram analisados conforme o modelo. 
$\mathbf{Y}_{\mathrm{i}}=\mu_{+} \mathbf{a}_{\mathrm{i}+} \mathbf{e}_{\mathrm{i}}$ em que: $\mathbf{Y}_{\mathrm{i}}=$ valor observado para o alimento i; $\mu=$ média geral; $\mathbf{a}_{\mathrm{i}}=$ efeito do alimento i; $(i=1,12) \mathbf{e}_{\mathrm{i}}=$ erro experimental associado a cada observação.

\section{Resultados e Discussão}

As frações "A", "B" e "C", as degradabilidades potencial (DP) e efetiva (DE) da MS e MO para taxas de passagem de 3,5 e $8 \% / h$ são mostradas nas Tabelas 2 e 3 . As sugestões de que o elevado teor de óleo de um alimento incubado pode obstruir os poros dos sacos de náilon e diminuir a degradação (MIR et al., 1984), não foram confirmadas neste estudo, visto que, o grão de girassol e soja integral apresentaram maiores degradabilidades quando comparados aos desengordurados.

As DE (5\%/h) do grão de girassol integral (extrato etéreo, 38,06\%) para MS e MO foram, respectivamente, $69,11 \%$ e $68,52 \%$, enquanto o girassol parcialmente desengordurado (extrato etéreo, $4,00 \%$ ) apresentou valores respectivos de $51,37 \% \mathrm{e}$ $49,60 \%,(\mathrm{P}<0,05)$. Esta diferença pode ser devido a uma maior solubilização dos componentes pelo óleo, o qual poderia ser responsável pelo maior desaparecimento de matéria dos sacos no tempo zero, já que o girassol integral apresentou valor para a fração solúvel da MS de 56,40\%, enquanto o girassol parcialmente desengordurado apresentou valor de $32,47 \%$ para a mesma fração.

Os valores citados acima para a fração solúvel, DE (5 e $8 \% / h)$ da MS do grão de girassol integral, foram superiores aos relatados por Bett (2002), $32,4 \%$ para a fração solúvel, 65,2 e 58,9\%, para DE a 5 e $8 \% / h$, respectivamente, para o grão de girassol quebrado, o que pode ser devido ao fato de que o grão de girassol usado neste experimento foi moído em moinho com peneiras de $2 \mathrm{~mm}$ de diâmetro.

Tabela 2. Frações solúveis (A), insolúveis potencialmente degradável (B), indigestível (C), degradabilidade potencial (DP) e degradabilidades efetiva(DE) da matéria seca (MS) para taxas de passagem no rúmen de 3, 5 e 8\%/h e coeficiente de variação (CV)

\begin{tabular}{|c|c|c|c|c|c|c|c|}
\hline \multirow[t]{2}{*}{ Alimentos } & \multicolumn{3}{|c|}{ Frações } & \multirow{2}{*}{ DP } & \multicolumn{3}{|c|}{$\begin{array}{c}\text { Degradabilidade efetiva a taxas de } \\
\text { passagem de }\end{array}$} \\
\hline & A & B & $\mathrm{C}$ & & $3 \% / \mathrm{h}$ & $5 \% / \mathrm{h}$ & $8 \% / \mathrm{h}$ \\
\hline GI & 56,40 & $19,27 \mathrm{e}$ & $24,33 \mathrm{~d}$ & $75,65 \mathrm{c}$ & $71,11 \mathrm{~b}$ & $69,11 \mathrm{c}$ & $66,96 \mathrm{c}$ \\
\hline GD & 32,47 & $27,31 \mathrm{~d}$ & $40,22 \mathrm{a}$ & $59,72 \mathrm{f}$ & $53,96 \mathrm{~g}$ & $51,37 \mathrm{f}$ & $48,53 \mathrm{~g}$ \\
\hline $\mathrm{FG}$ & 43,68 & $22,42 \mathrm{e}$ & $33,91 \mathrm{~b}$ & 66,09 e & $62,26 \mathrm{e}$ & $60,38 \mathrm{e}$ & 58,18 e \\
\hline $\mathrm{T} 1 \mathrm{x}$ & 50,12 & $13,19 \mathrm{f}$ & $36,69 \mathrm{ab}$ & $63,28 \mathrm{ef}$ & $59,83 \mathrm{f}$ & $58,38 \mathrm{e}$ & $56,86 \mathrm{ef}$ \\
\hline $\mathrm{T} 2 \mathrm{x}$ & 61,50 & $9,35 \mathrm{f}$ & $29,16 \mathrm{c}$ & $70,81 \mathrm{~d}$ & $68,31 \mathrm{~d}$ & $67,27 \mathrm{~cd}$ & $66,21 \mathrm{c}$ \\
\hline SI & 45,52 & $53,88 \mathrm{~b}$ & $1,10 \mathrm{f}$ & $98,90 \mathrm{a}$ & 89,35 a & $84,68 \mathrm{ab}$ & 79,29 a \\
\hline $\mathrm{SD}$ & 40,30 & 58,90 a & $0,80 \mathrm{f}$ & 99,19 a & 88,01 a & $82,65 \mathrm{~b}$ & $76,56 \mathrm{~b}$ \\
\hline FS & 46,60 & $52,00 \mathrm{~b}$ & $1,40 \mathrm{f}$ & $98,60 \mathrm{a}$ & 89,97 a & 85,66 a & 80,59 a \\
\hline $\mathrm{CA}$ & 30,45 & $29,87 \mathrm{~d}$ & $39,68 \mathrm{a}$ & $60,19 \mathrm{f}$ & $52,28 \mathrm{~g}$ & $48,99 \mathrm{~g}$ & $45,60 \mathrm{~h}$ \\
\hline FA & 35,64 & $36,51 \mathrm{c}$ & $27,85 \mathrm{~cd}$ & $72,07 \mathrm{~cd}$ & $62,73 \mathrm{e}$ & $58,76 \mathrm{e}$ & $54,60 \mathrm{f}$ \\
\hline GM & 45,38 & $39,58 \mathrm{c}$ & $15,05 \mathrm{e}$ & $83,99 \mathrm{~b}$ & $70,57 \mathrm{bc}$ & $65,66 \mathrm{~d}$ & $61,10 \mathrm{~d}$ \\
\hline $\mathrm{CC}$ & 53,16 & $21,61 \mathrm{e}$ & $25,23 \mathrm{~cd}$ & $74,63 \mathrm{~cd}$ & $68,50 \mathrm{~cd}$ & $66,03 \mathrm{~d}$ & $63,54 \mathrm{~d}$ \\
\hline CV (\%) & & 5,25 & 7,32 & 2,04 & 1,22 & 1,34 & 1,57 \\
\hline
\end{tabular}

GI- girassol integral; GD- girassol parcialmente desengordurado; FG- farelo de girassol; T 1x- torta de girassol com uma prensagem; T 2x- torta de girassol com duas prensagens; SI- soja integral; SD- soja parcialmente desengordurada; FSfarelo de soja; CA- caroço de algodão; FA- farelo de algodão; GM- gérmen de milho desengordurado; CC- concentrado comercial Letras diferentes na mesma coluna indicam médias diferentes $(\mathrm{P}<0,05)$ pelo teste Tukey 
Quando comparado ao grão de girassol também moído e parcialmente desengordurado, a fração solúvel da MS encontrada neste estudo 32,47\%, está muito próxima à relatada por Bett (2002), 32,4\%, porém as DE de $51,37 \%$ e $49,60 \%$, (5 e $8 \% /$ h) deste estudo, foram inferiores as relatadas pelo referido autor 65,2 e $58,9 \%$, para DE a 5 e $8 \% / \mathrm{h}$, respectivamente, provavelmente isto se deva aos processamentos diferentes. Para a MO os valores encontrados para a fração " $\mathrm{A}$ ” apresentaram o mesmo comportamento quando comparados com a MS, com o girassol integral apresentando $55,79 \%$ e o girassol parcialmente desengordurado $30,58 \%$.

A torta de girassol, obtida com uma passagem pela prensa, apresentou valores de DE de $58,38 \%$ e $56,95 \%$, respectivamente para MS e MO $(5 \% / \mathrm{h})$, inferiores aos encontrados para a torta de girassol obtida com duas passagens pela prensa $67,27 \%$ e $66,14 \%$, para MS e MO, respectivamente.

As frações solúveis encontradas para a MS e MO da torta de girassol obtida com uma passagem, foram $50,12 \%$ e $48,11 \%$ respectivamente, inferiores aos valores encontrados para a torta de girassol com duas passagens, os quais foram $61,50 \%$ e $59,63 \%$ respectivamente, para MS e MO. Este comportamento pode ser devido ao processo de prensagem que o grão de girassol integral foi submetido para retirada do óleo, pois, a segunda passagem da torta pela prensa causou uma maior impactação e consecutivo aquecimento, que após a moagem resultou em partículas menores ocasionando uma maior solubilização tanto para MS quanto para a MO, o que levou a maiores DE para a torta obtida com duas passagens, porém as frações potencialmente degradáveis tanto para MS quanto para MO foram menores para a torta com duas passagens.

O farelo de girassol apresentou DE da MS de $60,38 \%$ e $58,18 \%$, para taxas de passagem de 5 e $8 \% / \mathrm{h}$, respectivamente, valores superiores aos encontrados por Galati et al. (2002), de 55,00\% e $51,50 \%$, respectivamente, para as mesmas taxas de passagem apresentadas acima. Comportamento semelhante foi observado para a fração solúvel, $43,68 \%$ encontrado neste estudo e $38,70 \%$ relatados pelos referidos autores. A DE da MO apresentada neste estudo foi de $60,83(3 \% / \mathrm{h}), 58,91 \%(5 \% / \mathrm{h})$ e $56,69 \%(8 \% / h)$, para a fração solúvel o valor encontrado foi $41,83 \%$.

As DE $(5 \% / h)$ da MS e MO do farelo de soja foram de $85,66 \%$ e $85,28 \%$ respectivamente, não diferindo $(\mathrm{P}>0,05)$ da soja em grão integral com $84,68 \%$ para $\mathrm{MS}$ e $84,05 \%$ para $\mathrm{MO}$, sendo diferente $(\mathrm{P}<0,05)$ quando comparado à soja em grão parcialmente desengordurada com $82,65 \%$ e $81,91 \%$ para MS e MO, respectivamente, porém, este não difere da soja em grão integral. Silva et al. (2002) relataram valores de DE $(5 \% / \mathrm{h})$ da MS e MO de: $81,68 \%$ e $80,81 \%$ para o farelo de soja, $95,26 \%$ e $95,26 \%$ para soja em grão integral e 90,72\% e 90,72\% para soja em grão parcialmente desengordurada, respectivamente.

A fração solúvel da MS e MO do farelo de soja foram, respectivamente, $46,60 \%$ e $43,54 \%$, valor superior ao encontrado por Rossi Junior et al. (1997) para a fração "A" da MS, (37,34\%). A DE da MS a $3 \% / \mathrm{h}$ de taxa de passagem encontrada neste estudo, $89,97 \%$, foi superior a relatada pelos referidos autores, $81,09 \%$ a $3,74 \% / \mathrm{h}$ de taxa de passagem.

O grão de soja integral apresentou fração solúvel da MS de 45,52\% e 43,23\% da MO, inferiores aos valores apresentados por Silva et al. (2002), os quais foram $81,21 \%$ para a MS e $80,38 \%$ para a MO. No entanto, assim como ocorrido com o girassol integral e desengordurado neste estudo, o grão de soja integral (extrato etéreo, 21,05\%) apresentou maior solubilidade quando comparado ao grão de soja parcialmente desengordurado (extrato etéreo, $7,62 \%)$, os quais foram $40,30 \%$ e $37,52 \%$, respectivamente, para MS e MO, fato não observado por Brisola et al. (1998), que relataram 26,90\% de solubilidade da MS para o grão de soja semi-integral extrusado (teor de óleo, 11,8\%) e 23,89\% para o grão de soja integral extrusado (teor de óleo, 22,2\%). 
O farelo de algodão apresentou fração solúvel da MS de $35,64 \%$, e DE a 5 e $8 \% / h$ de $58,76 \%$ e $54,60 \%$, respectivamente, valores inferiores aos encontrados por Martins et al. (1998), os quais foram 42,8\% para a fração solúvel, $65,9 \%$ (DE 5\%/h) e $61,9 \%$ (DE $8 \% / \mathrm{h})$. O caroço de algodão apresentou valores menores para a fração solúvel da MS (30,45\%), assim como para as DE a $5 \% / \mathrm{h}(48,99 \%)$ e $8 \% / \mathrm{h}$ $(45,60 \%)$, o que pode ser devido ao fato do caroço de algodão apresentar maiores teores de cascas e linter, mesmo tendo maior teor de óleo.

Tabela 3. Frações solúveis (A), insolúveis potencialmente degradável (B), indigestível (C), degradabilidade potencial (DP) e degradabilidades efetiva (DE) da matéria orgânica (MO) para taxas de passagem no rúmen de 3, 5 e 8\%/h e coeficiente de variação (CV)

\begin{tabular}{|c|c|c|c|c|c|c|c|}
\hline \multirow[t]{2}{*}{ Alimentos } & \multicolumn{3}{|c|}{ Frações } & \multirow[b]{2}{*}{ DP } & \multicolumn{3}{|c|}{$\begin{array}{l}\text { Degradabilidade efetiva a taxas de } \\
\text { passagem de }\end{array}$} \\
\hline & A & B & $\mathrm{C}$ & & $3 \% / \mathrm{h}$ & $5 \% / \mathrm{h}$ & $8 \% / \mathrm{h}$ \\
\hline GI & 55,79 & $19,53 \mathrm{~h}$ & $24,66 \mathrm{~d}$ & $75,31 \mathrm{c}$ & $70,58 \mathrm{bc}$ & $68,52 \mathrm{c}$ & $66,33 \mathrm{c}$ \\
\hline GD & 30,58 & $27,60 \mathrm{ef}$ & $41,65 \mathrm{a}$ & $58,28 \mathrm{~g}$ & $52,27 \mathrm{f}$ & $49,60 \mathrm{f}$ & $46,67 \mathrm{f}$ \\
\hline FG & 41,83 & $22,69 \mathrm{hg}$ & $35,28 \mathrm{~b}$ & $64,72 \mathrm{e}$ & $60,83 \mathrm{e}$ & $58,91 \mathrm{e}$ & $56,69 \mathrm{~d}$ \\
\hline $\mathrm{T} 1 \mathrm{x}$ & 48,11 & $14,43 \mathrm{i}$ & $37,26 \mathrm{ab}$ & $62,67 \mathrm{ef}$ & $58,60 \mathrm{e}$ & $56,95 \mathrm{e}$ & $55,27 \mathrm{ed}$ \\
\hline $\mathrm{T} 2 \mathrm{x}$ & 59,63 & $10,90 \mathrm{i}$ & $29,17 \mathrm{c}$ & $70,72 \mathrm{~d}$ & $67,43 \mathrm{~d}$ & $66,14 \mathrm{c}$ & $64,88 \mathrm{c}$ \\
\hline SI & 43,23 & $55,39 \mathrm{~b}$ & $1,06 \mathrm{f}$ & $98,93 \mathrm{a}$ & 88,93 a & $84,05 \mathrm{ab}$ & $78,43 \mathrm{ab}$ \\
\hline SD & 37,52 & $61,27 \mathrm{a}$ & $0,89 \mathrm{f}$ & $99,10 \mathrm{a}$ & $87,47 \mathrm{a}$ & $81,91 \mathrm{~b}$ & $75,57 \mathrm{~b}$ \\
\hline FS & 43,54 & $54,73 \mathrm{~b}$ & $1,39 \mathrm{f}$ & $98,61 \mathrm{a}$ & 89,75 a & 85,28 a & $80,00 \mathrm{a}$ \\
\hline CA & 28,38 & $31,90 \mathrm{e}$ & $39,52 \mathrm{ab}$ & $60,34 \mathrm{fg}$ & $51,72 \mathrm{f}$ & $48,17 \mathrm{f}$ & $44,51 \mathrm{f}$ \\
\hline FA & 33,40 & $37,29 \mathrm{~d}$ & $29,08 \mathrm{c}$ & $70,84 d$ & $61,30 \mathrm{e}$ & $57,25 \mathrm{e}$ & $53,00 \mathrm{e}$ \\
\hline GM & 43,12 & $42,13 \mathrm{c}$ & $14,41 \mathrm{e}$ & $83,24 \mathrm{~b}$ & $68,03 \mathrm{~cd}$ & $62,76 \mathrm{~d}$ & $58,08 \mathrm{~d}$ \\
\hline $\mathrm{CC}$ & 52,27 & $25,27 \mathrm{fg}$ & $22,18 \mathrm{~d}$ & $77,70 \mathrm{c}$ & $71,07 \mathrm{~b}$ & $68,31 \mathrm{c}$ & $65,45 \mathrm{c}$ \\
\hline CV (\%) & & 5,31 & 7,74 & 2,27 & 1,73 & 1,81 & 1,92 \\
\hline
\end{tabular}

GI- girassol integral; GD- girassol parcialmente desengordurado; FG- farelo de girassol; T 1x- torta de girassol com uma prensagem; T 2x- torta de girassol com duas prensagens; SI- soja integral; SD- soja parcialmente desengordurada; FSfarelo de soja; CA- caroço de algodão; FA- farelo de algodão; GM- gérmen de milho desengordurado; CC- concentrado comercial. Letras diferentes na mesma coluna indicam médias diferentes $(\mathrm{P}<0,05)$ pelo teste Tukey

A fração solúvel e DE a 5\%/h encontradas neste estudo para o caroço de algodão foram superiores aos resultados obtidos por Teixeira et al. (2002) para DE a $5 \% / h(33,6 \%)$ e fração solúvel $(24,9 \%)$ da MS do caroço de algodão integral moído, porém a degradabilidade potencial relatada pelos referidos autores foi de 69,4\% (48h de incubação), a degradabilidade potencial para o caroço de algodão encontrada neste estudo foi de $60,19 \%$ (33h de incubação), inferior à anteriormente relatada.
Com relação à $\mathrm{MO}$ os valores encontrados apresentam o mesmo comportamento da MS, o farelo de algodão apresentou fração solúvel da MO de $33,40 \%$ e o caroço de algodão apresentou $28,38 \%$, as DE do farelo de algodão a 3,5 e $8 \% /$ h de taxa de passagem foram: $61,30 \%, 57,25 \%$ e $53,00 \%$, respectivamente. As DE do caroço de algodão para as mesmas taxas de passagem $(3,5$ e $8 \% / h)$ foram: $51,72 \%, 48,17 \%$ e $44,51 \%$ respectivamente. 
O farelo de gérmen de milho desengordurado neste estudo apresentou fração solúvel de 45,38\% e degradabilidade potencial de $83,99 \%$ para a MS, valores superiores aos 27,4\% para a fração solúvel e 73,4\% para a degradabilidade potencial da MS relatados por Galati (2004). As DE da MS para taxas de passagem de 3,5 e $8 \% / h$ foram: 70,57\%, 65,66\% e $61,10 \%$, respectivamente. Estes resultados foram superiores aos relatados por Galati (2004), DE de $53,3 \%$ de acordo com a taxa de passagem $(5,21 \%$ / h) obtida por Mendes (2003).

Para a MO o farelo de gérmen de milho apresentou fração solúvel de 43,12\%, degradabilidade potencial de $83,24 \%$ e DE a $3 \% / h$ de taxa de passagem de $68,03 \%$, a $5 \% / \mathrm{h}$ de taxa de passagem de $62,76 \%$ e para $8 \% / \mathrm{h}$ de taxa de passagem valor de $58,08 \%$.

O concentrado comercial (36\% de PB) apresentou valor para a fração solúvel da MS de 53,16\%, a DE da MS encontrada para este alimento foi $68,50 \%$ $(3 \% / \mathrm{h}), 66,03 \%(5 \% / \mathrm{h})$ e $63,54 \%(8 \% / \mathrm{h})$, e degradabilidade potencial de $74,63 \%$. A fração solúvel da MO do concentrado comercial (36\% de PB) também se comportou como a MS, com valor considerado alto, $52,27 \%$ e degradabilidade potencial de $77,70 \%$. As DE foram: $71,07 \%$ para taxa de passagem de $3 \% / \mathrm{h}, 68,31 \%$ para taxa de passagem de $5 \% / \mathrm{h}$ e $65,45 \%$ para taxa de passagem de $8 \% / \mathrm{h}$. $\mathrm{O}$ valor encontrado para a fração potencialmente degradável da MO foi 25,27\%.

O girassol parcialmente desengordurado (40,22\%), torta de girassol com uma passagem pela prensa $(36,69)$ e caroço de algodão $(39,68 \%)$, apresentaram as maiores porcentagens para a fração indegradável "C", possivelmente devido a maior quantidade de fibra destes alimentos. O grão de soja integral $(1,10 \%)$, grão de soja parcialmente desengordurado $(0,80 \%)$ e farelo de soja $(1,40 \%)$ apresentaram as menores porcentagens para a mesma fração, devido a alta solubilidade e as maiores porcentagens da fração potencialmente degradável " $\mathrm{B}$ " encontradas para estes alimentos. Com a MO o comportamento apresentou-se semelhante

As frações "A", "B" e "C", as degradabilidades potencial e efetiva da $\mathrm{PB}$ para taxas de passagem de 3,5 e $8 \% /$ h são mostradas na Tabela 4.

O grão de girassol integral e o girassol parcialmente desengordurado apresentaram as maiores $\mathrm{DE}$ da $\mathrm{PB}$, juntamente com as tortas de girassol com uma ou duas passagens pela prensa. $\mathrm{O}$ grão de girassol integral apresentou valores de DE da PB: $92,59 \%(3 \% / h), 90,70 \%(5 \% / h)$ e $88,38 \%$ $(8 \% / h)$, degradabilidade potencial de $96,17 \%$ e fração indegradável "C" de 3,89\%, valores semelhantes $(\mathrm{P}>$ $0,05)$ foram observados para o grão de girassol parcialmente desengordurado para a $\mathrm{DE}$ da $\mathrm{PB}$ : $92,65 \%(3 \% / \mathrm{h}), 90,67 \%(5 \% / \mathrm{h})$ e $88,12 \%(8 \% / \mathrm{h})$, degradabilidade potencial $(96,17 \%)$ e fração indegradável "C" $\mathrm{C}$ " $3,83 \%)$.

Para a fração solúvel da PB, o girassol integral apresentou valor superior $(69,08 \%)$, quando comparado ao grão de girassol parcialmente desengordurado (60,60\%), possivelmente devido ao maior escape de óleo do grão integral, estes valores foram superiores aos relatados por Bett (2002), $44,2 \%$ de solubilidade da PB para o grão de girassol quebrado.

As DE do grão de girassol integral e desengordurado foram semelhantes provavelmente devido à fração potencialmente degradável "B" do grão parcialmente desengordurado ter sido maior $(35,57 \%)(P>0,05)$ que a mesma fração do grão de girassol integral (27,09\%), compensando assim a maior solubilidade deste. Assim como ocorrido com a fração solúvel, as DE da PB 90,69\% (5\%/h) e $88,25 \%(8 \% / h)$ médias entre grão de girassol integral e parcialmente desengordurado encontradas neste estudo, foram superiores as relatadas por Bett (2002) para o grão de girassol quebrado, $80,9 \%(5 \% / \mathrm{h})$ e $74,7 \%(8 \% / \mathrm{h})$. 
Tabela 4. Frações solúveis (A), insolúveis potencialmente degradável (B), indigestível (C), degradabilidade potencial (DP) e degradabilidades efetiva (DE) da proteína bruta (PB) para taxas de passagem no rúmen de 3,5 e $8 \% / h$ e coeficiente de variação $(\mathrm{CV})$

\begin{tabular}{|c|c|c|c|c|c|c|c|}
\hline \multirow[t]{2}{*}{ Alimentos } & \multicolumn{3}{|c|}{ Frações } & \multirow[b]{2}{*}{ DP } & \multicolumn{3}{|c|}{$\begin{array}{c}\text { Degradabilidade efetiva a taxas de } \\
\text { passagem de }\end{array}$} \\
\hline & A & B & $\mathrm{C}$ & & $3 \% / \mathrm{h}$ & $5 \% / \mathrm{h}$ & $8 \% / \mathrm{h}$ \\
\hline GI & 69,08 & $27,09 \mathrm{e}$ & 3,89 cde & $96,17 \mathrm{~b}$ & $92,59 \mathrm{abc}$ & $90,70 \mathrm{bc}$ & $88,38 \mathrm{~b}$ \\
\hline GD & 60,60 & $35,57 \mathrm{~d}$ & $3,83 \mathrm{cde}$ & $96,17 \mathrm{~b}$ & $92,65 \mathrm{abc}$ & $90,67 \mathrm{bc}$ & $88,12 \mathrm{~b}$ \\
\hline $\mathrm{FG}$ & 73,25 & $22,56 \mathrm{f}$ & $4,17 \mathrm{c}$ & $95,84 \mathrm{~b}$ & $91,80 \mathrm{bc}$ & $89,83 \mathrm{c}$ & $87,57 \mathrm{~b}$ \\
\hline $\mathrm{T} 1 \mathrm{x}$ & 89,47 & $6,61 \mathrm{~h}$ & $3,92 \mathrm{c}$ & $96,08 \mathrm{~b}$ & $95,01 \mathrm{ab}$ & $94,48 \mathrm{ab}$ & 93,85 a \\
\hline $\mathrm{T} 2 \mathrm{x}$ & 92,82 & $4,04 \mathrm{~h}$ & $3,14 \mathrm{cdef}$ & $96,86 \mathrm{ab}$ & $96,24 \mathrm{a}$ & 95,93 a & 95,56 a \\
\hline SI & 36,44 & $63,21 \mathrm{~b}$ & $0,35 \mathrm{ef}$ & 99,64 a & $89,76 \mathrm{c}$ & 84,74 de & $78,76 \mathrm{~cd}$ \\
\hline $\mathrm{SD}$ & 37,69 & $62,06 \mathrm{~b}$ & $0,26 \mathrm{f}$ & 99,75 a & $90,13 \mathrm{c}$ & $85,23 \mathrm{~d}$ & $79,39 \mathrm{~cd}$ \\
\hline FS & 28,30 & $71,22 \mathrm{a}$ & 0,48 edf & 99,52 a & $91,15 \mathrm{c}$ & $86,56 \mathrm{~cd}$ & $80,86 \mathrm{c}$ \\
\hline $\mathrm{CA}$ & 77,61 & $16,14 \mathrm{~g}$ & $6,25 \mathrm{c}$ & $93,75 \mathrm{~b}$ & $91,14 \mathrm{c}$ & $89,84 \mathrm{c}$ & $88,30 \mathrm{~b}$ \\
\hline FA & 41,51 & $53,27 \mathrm{c}$ & $5,22 \mathrm{c}$ & $94,77 \mathrm{~b}$ & $85,35 \mathrm{~d}$ & 80,79 e & $75,56 \mathrm{~d}$ \\
\hline GM & 31,99 & $51,09 \mathrm{c}$ & $16,92 \mathrm{~b}$ & $82,80 \mathrm{c}$ & $68,51 \mathrm{e}$ & $62,71 \mathrm{f}$ & $56,81 \mathrm{e}$ \\
\hline $\mathrm{CC}$ & 48,34 & $25,70 \mathrm{ef}$ & 25,96 a & $73,49 \mathrm{~d}$ & $65,18 \mathrm{e}$ & $62,08 \mathrm{f}$ & $59,12 \mathrm{e}$ \\
\hline $\mathrm{VV}(\%)$ & & 3,89 & 22,96 & 1,45 & 1,71 & 2,01 & 2,29 \\
\hline
\end{tabular}

GI- girassol integral; GD- girassol parcialmente desengordurado; FG- farelo de girassol; T 1x- torta de girassol com uma prensagem; T 2x- torta de girassol com duas prensagens; SI- soja integral; SD- soja parcialmente desengordurada; FSfarelo de soja; CA- caroço de algodão; FA- farelo de algodão; GM- gérmen de milho desengordurado; CC- concentrado comercial Letras diferentes na mesma coluna indicam médias diferentes $(\mathrm{P}<0,05)$ pelo teste Tukey

A exemplo do grão de girassol integral ou parcialmente desengordurado, as tortas de girassol com uma ou duas passagens pela prensa, também apresentaram valores semelhantes $(\mathrm{P}>0,05)$ para as DE da PB, sendo $95,01 \%(3 \% / \mathrm{h}), 94,48 \%(5 \% / \mathrm{h})$ e $93,85 \%(8 \% / \mathrm{h})$ para a torta com uma passagem e $96,24 \%(3 \% / \mathrm{h}), 95,93 \%(5 \% / \mathrm{h})$ e $95,56 \%(8 \% / \mathrm{h})$ para a torta com duas passagens pela prensa.

Valores semelhantes $(\mathrm{P}>0,05)$ também foram observados para a degradabilidade potencial, fração indegradável "C" e fração potencialmente degradável "B", 96,08\%, 3,92\% e 6,61\%, respectivamente, para torta com uma passagem, $96,86 \%, 3,14 \%$ e $4,04 \%$, respectivamente, para a torta com duas passagens. A fração solúvel da PB da torta de girassol com uma passagem foi pouco inferior $(89,47 \%)$, quando comparada a torta com duas passagens $(92,82 \%)$, porém segue o mesmo comportamento observado para estes dois alimentos com relação a MS e MO.
O farelo de girassol apresentou valores para a DE da PB para taxas de passagem de $3 \% / \mathrm{h}$ $(91,80 \%), 5 \% / \mathrm{h}(89,83 \%)$ e $8 \% / \mathrm{h}(87,57 \%)$, valores superiores aos encontrados por Galati et al. (2002), de $83,20 \%$ para $5 \% /$ h de taxa de passagem e $78,70 \%$ para $8 \% / \mathrm{h}$ de taxa de passagem. Comportamento semelhante também foi observado para a fração solúvel da PB, 73,25\% encontrado neste estudo e $56,30 \%$ relatados pelos referidos autores. No entanto, a fração indegradável " $C$ " da $\mathrm{PB}$, encontrada neste estudo $4,17 \%$, foi superior aos $2,70 \%$ relatado pelos referidos autores.

O grão de soja integral, grão de soja parcialmente desengordurado e farelo de soja, apresentaram neste estudo valores semelhantes $(\mathrm{P}>0,05)$ para as $\mathrm{DE}$ a 3,5 e $8 \% /$ h de taxa de passagem, degradabilidade potencial e fração indegradável " $C$ " da $\mathrm{PB}$. 
Dentre os alimentos estudados, os que apresentaram as maiores degradabilidades potenciais da PB foram: grão de soja parcialmente desengordurado $(99,75 \%)$, grão de soja integral $(99,64 \%)$ e farelo de soja $(99,52 \%)$, os quais apresentaram também as menores porcentagens para a fração indegradável " $\mathrm{C}$ " da $\mathrm{PB}$, sendo o farelo de soja $(0,48 \%)$, grão de soja integral $(0,35 \%)$ e grão de soja parcialmente desengordurado $(0,26 \%)$.

As DE da PB do grão de soja integral foram: $89,76 \%(3 \% / \mathrm{h}), 84,74 \%(5 \% / \mathrm{h})$ e $78,76 \%(8 \% / \mathrm{h}) \mathrm{de}$ taxas de passagem, para o grão de soja parcialmente desengordurado as DE da PB encontradas foram: $90,13 \%(3 \% / \mathrm{h}), 85,23 \%(5 \% / \mathrm{h})$ e $79,39 \%(8 \% / \mathrm{h})$ e para o farelo de soja as DE da PB observadas neste estudo foram: $91,15 \%(3 \% / \mathrm{h}), 86,56 \%(5 \% / \mathrm{h})$ e $80,86 \%(8 \% / \mathrm{h})$. Estes alimentos apresentaram menores degradabilidades efetivas quando comparados ao girassol e seus co-produtos, diferindo $(\mathrm{P}<0,05)$ para todas as taxas de passagem somente das tortas de girassol com uma ou duas passagens pela prensa.

O grão de soja integral apresentou, neste estudo, fração solúvel da PB (36,44\%) valor bem inferior ao relatado por Silva et al. (2002) (87,82\%), Cabral et al. (2000) (50,40\%), no entanto a fração indegradável "C" da $\mathrm{PB}$ encontrada neste trabalho, $(0,35 \%)$ foi inferior a relatada por Cabral et al. (2000) (4,40\%). A degradabilidade potencial da PB apresentada neste estudo $(99,64 \%)$ foi semelhante a relatada por Silva et al. (2002). A DE da PB a 5\%/h de 84,74\%, valor encontrado neste trabalho, foi inferior a relatada por Silva et al. (2002) para a mesma taxa de passagem, 97,82\%, e Vilela, Valadares Filho e Silva (1994), 88,20\%.

O grão de soja parcialmente desengordurado (7,62\% de EE) apresentou neste estudo 37,69\% para a fração solúvel da PB, valor bem superior ao relatado por Brisola et al. (1998) para a soja semi-integral extrusada (11,8\% teor de óleo), 8,56\% para a mesma fração, no entanto Silva et al. (2002) relataram valor bem superior para a soja parcialmente desengordurada, $88,69 \%$. Silva et al. (2002) relataram valor para a degradabilidade potencial e efetiva (5\%/ h) da PB de 99,99\% e 98,05\% respectivamente, superiores aos encontrados neste estudo, 99,75\% para a degradabilidade potencial e $85,23 \%$ para a DE $(5 \% / h)$.

O farelo de soja apresentou $28,30 \%$ para a fração solúvel da $\mathrm{PB}$, neste estudo, valor superior aos encontrados na literatura, $(8,23 \%),(8,26 \%),(11,80 \%)$ e $(22,30 \%)$ citados por Cabral et al. (2000), Malafaia, Valadares Filho e Vieira (1997), Brisola et al. (1998) e Martins et al. (1998), respectivamente. Sousa et al. (2002), Rossi Junior et al. (1997) e Silva et al. (2002) relatam valores superiores, $(35,40 \%)$, $(40,53 \%)$ e $(56,99 \%)$ para a mesma fração.

A fração não degradável "C" da PB do farelo de soja encontrada neste estudo $0,48 \%$, foi superior aos valores relatados por Brisola et al. (1998) $(0,18 \%)$ e Rossi Junior et al. (1997) (0,18\%) para dieta com $82 \%$ de volumoso, e inferior aos também divulgados por Rossi Junior et al. (1997) (0,55\%) para dieta com $61 \%$ de volumoso, por Cabral et al. (2000) (0,98\%), Malafaia, Valadares Filho e Vieira (1997) (1,38\%) e Sousa et al. (2002) com 2,7\% de fração não degradável.

$\mathrm{O}$ valor para a degradabilidade potencial da $\mathrm{PB}$ do farelo de soja encontrado neste estudo, 99,52\%, foi superior aos relatados por Rossi Junior et al. (1997), de $98,82 \%$ para dieta com $82 \%$ de volumoso e $96,93 \%$ para dieta com $61,00 \%$ de volumoso, Sousa et al. (2002) apresentaram valor de 90,30\%, Brisola et al. (1998) (98,87\%) e Silva et al. (2002) (97,20\%) para a degradabilidade potencial da $\mathrm{PB}$.

A DE da PB do farelo de soja encontrada neste estudo para $3 \% / \mathrm{h}$ de taxa de passagem foi $91,15 \%$, valor superior ao encontrado por Rossi Junior et al. (1997) 86,06\%, com taxa de passagem de 3,74\%/h. A DE da PB do farelo de soja para taxa de passagem de $5 \% / \mathrm{h}$ encontrada neste estudo foi $86,56 \%$, valor próximo ao relatado por Silva et al. (2002) de 85,22\%, superior aos valores encontrados por Sousa et al. (2002) 62,90\% e Vilela, Valadares Filho e Silva (1994) $70,70 \%$, para a mesma taxa de passagem. 
O farelo de algodão apresentou fração solúvel da $\mathrm{PB}$ de $41,51 \%$, valor inferior ao encontrado para o caroço de algodão, $77,61 \%$, assim como para as DE da $\mathrm{PB}, 85,35 \%(3 \% / \mathrm{h}), 80,79 \%(5 \% / \mathrm{h})$ e $75,56 \%$ $(8 \% / h)$ de taxas de passagem do farelo de algodão e $91,14 \%(3 \% / \mathrm{h}), 89,84 \%(5 \% / \mathrm{h})$ e $88,30 \%$ (8\%/h) de DE da PB para o caroço de algodão, $(\mathrm{P}<0,05)$, podendo ser devido à maior solubilidade encontrada no tempo zero e possivelmente ao aquecimento durante o processo de extração de óleo, o qual pode causar uma mudança na constituição da proteína, diminuindo assim a degradabilidade.

As degradabilidades potencial e fração não degradável "C", não apresentaram diferença (P> $0,05)$, entre o farelo de algodão $94,77 \%$ e $5,22 \%$ e o caroço de algodão $93,75 \%$ e 6,25\%, respectivamente, sendo que a fração não degradável " $C$ " do farelo de algodão, apresentou valor próximo aos relatados por Malafaia, Valadares Filho e Vieira (1997) 3,06\%, e Cabral et al. (2000) 5,06\%.

No presente estudo a fração solúvel da $\mathrm{PB}$ encontrada para o farelo de algodão, 41,51\%, foi inferior ao relatado por Martins et al. (1998), de $47,50 \%$, porém superior aos divulgados por Malafaia, Valadares Filho e Vieira (1997) (3,68\%) e Cabral et al. (2000) (18,28\%). As DE da PB do farelo de algodão a 5 e $8 \% / \mathrm{h}, 80,79$ e $75,56 \%$ encontrados neste estudo são bem próximos as apresentadas por Martins et al. (1998), 81,40\% e 76,00\%, respectivamente, para as mesmas taxas de passagem. Vilela, Valadares Filho e Silva (1994) relata DE da PB a 5\%/h de taxa de passagem para o farelo de algodão de $63,40 \%$.

O caroço de algodão apresentou neste estudo, fração solúvel, DE a 5\%/h e degradabilidade potencial da PB de 77,61\%, 89,84\% e 93,75\% respectivamente, valores superiores aos relatados por Teixeira et al. (2002), de 36,5\%, para a fração solúvel, 55,20\% para a DE $(5 \% / \mathrm{h})$ da $\mathrm{PB}$ e $67,00 \%$ para a degradabilidade potencial da PB. A DE da PB encontrada neste estudo, também foi superior a relatada por Vilela, Valadares Filho e Silva (1994) para DE da PB a 5\%/ h, 33,70\%.
Neste trabalho o gérmen de milho desengordurado apresentou 31,99\% para a fração solúvel e 82,80\% para a degradabilidade potencial da $\mathrm{PB}$, valores superiores aos encontrados por Galati, Ezequiel e Mendes (2004), fração solúvel de 20,30\% e degradabilidade potencial de $78,30 \%$ para a PB. A fração não degradável "C" apresentada, 16,92\% está próxima a relatada pelo referido autor, $18,6 \%$. As DE da PB para taxas de passagem de 3,5 e $8 \% / \mathrm{h}$ foram: $68,51 \%, 62,71 \%$ e $56,81 \%$ respectivamente, por Galati, Ezequiel e Mendes (2004) relatou DE de $54,60 \%$ de acordo com a taxa de passagem $(5,21 \% /$ h) obtida por Mendes (2003).

O concentrado comercial ( $36 \%$ de PB) apresentou valor para a fração solúvel da $\mathrm{PB}$ de $48,34 \%$, a DE da PB encontrada para este alimento foi $65,18 \%$ (3\%/ h), $62,08 \%(5 \% / \mathrm{h})$ e $59,12 \%(8 \% / \mathrm{h})$ e degradabilidade potencial de $73,49 \%$. A fração potencialmente degradável da PB do concentrado comercial foi $25,70 \%$

\section{Conclusões}

Os teores de óleo não influenciaram as $\mathrm{DE}$ da $\mathrm{PB}$, a 3, 5 e $8 \%$ de taxas de passagem entre o girassol integral e parcialmente desengordurado, influenciando as DE da MS e MO, a 3, 5 e $8 \%$, onde o girassol integral apresentou-se mais degradável.

O número de passagens pela prensa, aplicado sobre a torta de girassol também não influenciou as $\mathrm{DE}$ da $\mathrm{PB}(3,5$ e $8 \% / \mathrm{h})$. No entanto, as DE da MS e MO para as mesmas taxas de passagem diferiram entre as tortas com uma ou duas passagens, sendo mais degradável a torta com duas passagens.

Os alimentos compostos por girassol apresentaram valores próximos para as degradabilidades efetivas da PB para as três taxas de passagem, sugerindo que os mesmos podem substituir uns aos outros, devendo-se atentar para a quantidade de óleo suportada pelo rúmen. Comportamento semelhante foi observado para os alimentos compostos por soja. 
O caroço de algodão apresentou valores para as degradabilidades efetivas da $\mathrm{PB}$ próximos aos valores do grão de girassol integral, desengordurado e farelo de girassol, sugerindo que este alimento pode substituir os citados por apresentarem características de degradação semelhantes.

O concentrado comercial e o farelo de gérmen de milho desengordurado apresentaram as menores degradabilidades efetiva e potencial da PB, sugerindo que estes alimentos têm maior capacidade de fornecer maiores porcentagens de proteína nos intestinos, porém em quantidade, somente o concentrado comercial teria eficiência, pois o gérmen de milho apresenta em sua constituição apenas 10,79\% de PB.

\section{Referências}

AGRICULTURAL AND FOOD RESEARCH COUNCILAFRC. Energy and protein requirements of ruminants. Wallingford: CAB International. p. 119, 1993.

BETT, V. Grãos de girassol (Helianthus annuus) em rações para vacas leiteiras. 2002. 147 f. Tese (Doutorado em Zootecnia) - Faculdade de Ciências Agrárias e Veterinárias, Universidade Estadual Paulista, Jaboticabal, 2002.

BRISOLA, M. L.; LUCCI, C. S.; MELOTTI, L.; KODAIRA, V. Degradabilidade ruminal "in situ" da proteína de grãos de soja extrusados e do farelo de soja. In: REUNIÃO ANUAL DA SOCIEDADE BRASILEIRA DE ZOOTECNIA, 35., 1998, Botucatu. Anais... Botucatu: SBZ, 1998.p. 59-61.

CABRAL, L. S.; VALADARES FILHO, S. C.; MALAFAIA, P. A. M.; LANA, R. P.; SILVA, J. F. C.; VIEIRA, R. A. M.; PEREIRA, E. S. Frações protéicas de alimentos tropicais e suas taxas de digestão estimadas pela incubação com proteases ruminais. Revista Brasileira de Zootecnia, Viçosa, v.29, n.26, p.2316-2324, 2000.

GALATI, R. L.; EZEQUIEL, J. M. B.; MENDES, A. R.. Cinética da digestão ruminal "in situ" do farelo de girassol utilizado em dietas para bovinos. In: REUNIÃO ANUAL DA SOCIEDADE BRASILEIRA DE ZOOTECNIA, 39. 2002, Recife. Anais... Recife: SBZ, 2002. (CD-ROM)

GALATI. R. L. Co-produtos do milho, soja e girassol para bovinos de corte. 2004. $167 \mathrm{f}$. Tese (Doutorado em Zootecnia) - Faculdade de Ciências Agrárias e Veterinárias, Universidade Estadual Paulista, Jaboticabal. 2004.
MALAFAIA, P. A. M.; VALADARES FILHO, S. C.; VIEIRA, R. A. M. Determinação e cinética ruminal das frações protéicas de alguns alimentos para ruminantes. Revista Brasileira de Zootecnia, Viçosa, v. 26, n.6, p. 1243 1251, 1997.

MARTINS, A. S.;ZEOULA, L. M.; PRADO, I.N.; MARTINS, E. N.; LOYOLA, V. R. Degradabilidade ruminal "in situ" da matéria seca e proteína bruta das silagens de milho e sorgo e de alguns alimentos concentrados. Revista Brasileira de Zootecnia, Viçosa, v. 28, n. 5, p. 1109-1117, 1999.

MARTINS, A. S.; ZEOULA, L. M.; PRADO, I. N.; MICHELAN, A. C. Degradação ruminal da matéria seca e proteína bruta de alguns alimentos. In: REUNIÃO ANUAL DA SOCIEDADE BRASILEIRA DE ZOOTECNIA, 35. 1998, Botucatu. Anais... Botucatu: SBZ 1998. p. 374-376.

MENDES, A. R. Fontes energéticas associadas ao farelo de girassol em dietas para bovinos em confinamento. 2003, 103 f. Tese (Doutorado em Zootecnia) - Faculdade de Ciências Agrárias e Veterinárias, Universidade Estadual Paulista, Jaboticabal, 2003.

MIR, Z.; MAcLEOD, G. K.; BUCHANAN-SMITTH, J. G.; GRIEVE, D. G.; GROVUM, W. L. Methods for protecting soybean and canola proteins from degradation in the rumen. Candian Journal of Animal Science, Ottawa, v. 64, p. 853-865, 1984.

NATIONAL RESEARCH COUNCIL - NRC. Nutrient requirements of dairy cattle. $6^{\text {th }}$ ed. Washington: National Academy Press, $1989.157 \mathrm{p}$.

NATIONAL RESEARCH COUNCIL-NRC. Ruminant nitrogen usage. Washington: National Academy Press, 1985. $138 \mathrm{p}$.

ORSKOV, E. R.; McDONALD, I. The estimation of protein degradability in the rumen from incubation measurements weighted according to rate of passage. Journal of Agricultural Science, Cambridge, v.92, p.499-503, 1979.

ROSSI JUNIOR, P.; SILVA, A. G.; WANDERLEY, R. C.; BOSE, M. L. V.; BOIN, C. Degradabilidade ruminal da matéria seca e da fração protéica da silagem de milho, do farelo de soja e sorgo grão, em bovinos da raça nelore. Comparação com os dados obtidos pelo CNCPS. Revista Brasileira de Zootecnia, Viçosa, v.26, n.4, p.599-607, 1997.

SAS Institute. SAS user's guide: version $6.4^{\text {th }}$ ed. Cary, $1990.956 \mathrm{p}$.

SILVA, D. J.; QUEIROZ, A. C. Análises de alimentos: métodos químicos e biológicos. 3.ed. Viçosa: UFV, 2002. $235 \mathrm{p}$. 
SILVA, L. D. F.; RAMOS, B. M. O.; RIBEIRO, E. L. A.; MIZUBUTI, I. Y.; ROCHA, M. A.; MORAES, F. L. Z. Degradabilidade ruminal "in situ" da matéria seca e proteína bruta de duas variedades de grão de soja com diferentes teores de inibidor de tripsina em bovinos. Revista Brasileira de Zootecnia, Viçosa, v.31, n.3, p.12511257, 2002.

SOUSA, M. S.; EZEQUIEL, J. M. B.; ROSSI JUNIOR, P.; MALHEIROS, E. B. Efeitos de fontes nitrogenadas com distintas degradabilidades sobre o aproveitamento da fibra, do nitrogênio e do amido em rações para bovinos. Revista Brasileira de Zootecnia, Viçosa, v.31, n.4, p.21392148, 2002.

TEIXEIRA, J. C.; SILVA, E. A.; BRAGA, R. A. N.; MORON, I. R. Cinética da digestão ruminal do caroço de algodão e do grão de milho em diferentes formas físicas em vacas holandesas. Ciência e Agrotecnologia, Lavras, v.26, n.4, p.842-845, 2002.
VALADARES FILHO, S. C.; VALADARES, R. F. D. Recentes avanços em proteína na nutrição de vacas leiteiras. In: SIMPÓSIO INTERNACIONAL EM BOVINOCULTURA DE LEITE, 2., 2001, Lavras. Anais...Lavras: UFL, 2001. p. 229-247.

VILELA, G. L.; VALADARES FILHO, S. C.; SILVA, J. F. C. Degradabilidade "in situ" da matéria seca e da proteína bruta de vários alimentos. In: REUNIÃO ANUAL DA SOCIEDADE BRASILEIRA DE ZOOTECNIA, 31., 1994, Maringá. Anais...,Maringá: SBZ, 1994. p. 535. 